\title{
Renal Failure after Radiological Contrast Media
}

\author{
J. MCEVOY, ${ }^{*}$ M.D., M.R.C.P. ; M. G. MCGEOWN, $†$ M.D., PH.D., F.R.C.P.ED. ; R. KUMAR, $\ddagger$ M.D.
}

British Medical fournal, 1970, 4, 717-718

\begin{abstract}
Summary: Over a 12-month period four patients developed acute renal failure after undergoing radiological investigations using contrast media. Though the incidence of serious complications is low, the possibility of adverse side effects must be weighed against the usefulness of the information provided by these techniques.
\end{abstract}

\section{Introduction}

In normal circumstances diagnostic radiocontrast media are safe and cause little if any upset to the patients under investigation. In recent years there has been a tendency to advocate ever-increasing doses of these contrast media to obtain adequate pictures when the renal or hepatic excretory mechanisms are impaired (Schwartz et al., 1963; Kelsey Fry and Cattell, 1970). However, in the presence either of preexisting renal insufficiency or of jaundice with its known tendency to potentiate nephrotoxic agents they may precipitate an acute or acute on chronic episode of renal failure. We report four such cases seen in the period March 1969 to April 1970. Two arose as a complication of renal arteriography, while the other two resulted from attempts at intravenous cholangiography in the presence of jaundice.

\section{Case 1}

A 74-year-old man was first seen at another hospital on 28 March 1969 complaining of thirst and polyuria. His urine did not contain sugar, but a blood pressure of $290 / 160 \mathrm{~mm}$. Hg was noted along with papilloedema, exudates, and haemorrhages in both optic fundi. Blood urea on admission was $69 \mathrm{mg}$. $/ 100 \mathrm{ml}$., with a normal electrolyte block. An intravenous pyelogram on 1 April showed a right kidney measuring $10.5 \mathrm{~cm}$. along its bipolar axis, and on the left side a large rounded mass expanding the upper pole of the kidney and extending as far as the inferior diaphragmatic surface. The appearances were thought consistent with either hypernephroma or simple cyst of the kidney, and arteriography was advocated to differentiate between those two lesions. On 8 April the blood urea was $67 \mathrm{mg} . / 100 \mathrm{ml}$. An aortogram and selective left renal arteriogram carried out on 22 April showed the lesion of the left upper pole to be a large simple cyst. A pronounced stenosis of the right renal artery was also noted, and the flow through both kidneys was very slow. Blood urea on 23 April was $110 \mathrm{mg} . / 100 \mathrm{ml}$., rising to $280 \mathrm{mg}$. on 2 May despite conservative measures for the treatment of acute renal failure. Urinary output on 2 May was down to $270 \mathrm{ml}$./24 hours.

He was admitted to this unit on 2 May and treated by peritoneal dialysis, intravenous fluids, and a $20-\mathrm{g}$. protein acute renal failure diet. Within five days his urinary output had increased to over $1,500 \mathrm{ml} . / 24$ hours, and he was able to reduce his blood urea without further dialysis. He was discharged to continue convalescence in the hospital which he first attended.

\section{Case 2}

A 67-year-old man was seen at the outpatient department of another hospital complaining of haematuria. His blood urea was $25 \mathrm{mg} . / 100 \mathrm{ml}$. on $18 \mathrm{March} \mathrm{1970.} \mathrm{An} \mathrm{intravenous} \mathrm{pyelogram} \mathrm{on}$ 20 March indicated a lesion on the right side. On 23 March the urea was $30 \mathrm{mg} . / 100 \mathrm{ml}$. A selective right renal arteriogram on 24 March showed a hypernephroma in the right kidney, which

\footnotetext{
* Consultant Nephrologist, Belfast and South Belfast Hospital Groups, Belfast BT9 7AB

+ Consultant Medical Urologist, Belfast and South Belfast Hospital

¥ Registrar, Renal Unit, Belfast City Hospital
}

was removed the following day. The tumour was well encapsulated and measured 1 in. $(2.5 \mathrm{~cm}$.) in diameter. Postoperatively the urea rose progressively to a maximum of $380 \mathrm{mg} . / 100 \mathrm{ml}$. on 8 April and then fell gradually to $64 \mathrm{mg}$. by the $24 \mathrm{th}$. Only conservative measures were needed to manage the renal failure and dialysis was not required. Subsequent investigation in the postoperative period showed that he was suffering from unsuspected myelomatosis, with Bence-Jones proteinuria, lucid areas in the vault of the skull, and IgG greater than $3,000 \mathrm{mg} . / 100 \mathrm{ml}$. The sternal marrow showed a pronounced infiltration with small plasma cells but no evidence of carcinomatous infiltration. He was alive and reasonably well in September 1970 with a blood urea of $56 \mathrm{mg} . / 100 \mathrm{ml}$.

\section{Case 3}

A 46-year-old man had been extensively investigated in another hospital over the previous five years for jaundice. The origin of this remains obscure, though the laboratory findings suggest an obstructive type of lesion. Several other members of his family are also said to have developed jaundice at about the same age as he did. On 14 February 1969 his blood urea was $27 \mathrm{mg} . / 100 \mathrm{ml}$, total bilirubin $7.1 \mathrm{mg} . / 100 \mathrm{ml}$., direct $7.0 \mathrm{mg}$. An intravenous cholangiogram was attempted on 2 June, but the liver failed to excrete the dye, so a second attempt with $200 \mathrm{ml}$. of Biligrafin in $1,000 \mathrm{ml}$. of $5 \%$ dextrose was made on 24 June. This was also unsuccessful. A third attempt with still larger volumes of contrast medium was under consideration, but was frustrated by the patient, who developed malaise, vomiting, and epigastric discomfort 24 hours after the second examination. By 26 June his blood urea was $146 \mathrm{mg} . / 100 \mathrm{ml}$., rising to $375 \mathrm{mg}$. on 30 June, the date of his transfer to this unit. He was anuric.

Treatment was started with peritoneal dialysis, appropriate fluid and electrolyte replacement, and a 20 -g. protein acute renal failure diet. Over the next three weeks his urinary output rose gradually to $3,870 \mathrm{ml} . / 24$ hours; and his blood urea decreased spontaneously without further dialysis. At an outpatient review on 8 August he had returned to normal health except for the jaundice, and his blood urea was $38 \mathrm{mg} . / 100 \mathrm{ml}$. on a normal diet.

\section{Case 4}

A 38-year-old woman with Down's syndrome was known to have had stones in a non-functioning gall bladder for some years. Repeated episodes of acute cholecystitis led to operative removal of the gall bladder in this hospital in March 1969, from which she made a good recovery. Her blood urea at this time was within normal limits. On 5 September 1969 she was admitted to another hospital with a history of prolonged vomiting, and on examination was found to be dehydrated and deeply jaundiced-total bilirubin $9.8 \mathrm{mg}$. $/ 100 \mathrm{ml}$., direct $9.2 \mathrm{mg}$. On 6 September her blood urea was $90 \mathrm{mg} . / 100 \mathrm{ml}$. with the following serum electrolyte block: sodium 136, potassium 3.1 , chloride $98, \mathrm{CO}_{2}$ combining power $20 \mathrm{mEq} / \mathrm{l}$. and plasma S.G. 1029. The findings in the blood and in the urine indicated that the jaundice was obstructive in origin, and a presumptive diagnosis of stone in the common bile duct was made. She was treated with intravenous fluids and electrolytes and the blood urea dropped to $20 \mathrm{mg}$. $/ 100 \mathrm{ml}$. On 9 September an intravenous cholangiogram was carried out. This was unhelpful in that the liver failed to excrete the contrast medium and no opaque calculi were seen. On 13 September her blood urea had risen to $356 \mathrm{mg} . / 100 \mathrm{ml}$. and she was then transferred to this unit, where she was found to be hypotensive, the blood pressure $80 / 60 \mathrm{~mm}$. Hg; and she had a tachycardia which was at times uncountable even on auscultation.

Electrocardiography showed sinus tachycardia with anterolateral ischaemia but no definite infarction. Peritoneal dialysis was begun and the appropriate intravenous fluids were continued. The urinary output over the first 24 hours was $960 \mathrm{ml}$. and by the fourth day here it had risen to $2,190 \mathrm{ml}$., but the blood urea remained at almost the same level. Peritoneal dialysis was tech- 
nically unsatisfactory, partly because of her mental state, and haemodialysis could not be undertaken because of her low blood pressure and general condition, which failed to improve despite appropriate supportive treatment. She deteriorated further and died on 24 September. Unfortunately necropsy was not carried out. We cannnot, therefore, rule out the possibility that the second episode of renal failure may have been due to something other than the contrast medium-for example, septicaemia or rupture of the common bile duct. There was, however, no clinical evidence pointing specifically towards any such complication; she was provided with broad-spectrum antibiotic cover, and the peritoneal effluent was not suggestive of perforation of any viscus.

\section{Discussion}

Intravenous and intra-arterial contrast media are so widely and safely used, as to be regarded as virtually non-toxic. Schwartz et al. (1963) first advocated using a larger than normal dosage to improve the intravenous pyelogram in renal failure. The drip infusion technique was introduced by Schencker (1964). Since then there have been numerous published reports of successful visualization of the urinary tracts when using high-dose urography, and these have continued right up to the present time (Kelsey Fry and Cattell, 1970).

Various authors, however, have drawn attention to the risks involved. Manitz and Matthes (1967) and Ansell (1968) reported temporary anuria as a complication of intravenous pyelography in patients with renal failure. Chamberlain and Gleeson (1965) concluded that the morbidity and mortality of renal angiography are such as to make it unjustified in the investigation of hypertension. Renal failure is not listed among their complications but clearly needs to be taken into account. The danger of acute renal failure after pyelography in myeloma is well known, though Lasser et al. (1966) produced clinical and experimental evidence that this is less likely with the newer contrast media. The fact that Case 2 survived his I.V.P. without any rise in blood urea is in keeping with their findings. Whether the subsequent deterioration after the arteriogram was due to precipitation of myeloma protein as a result of the contrast arriving in the kidney at a higher concentration than is achieved during pyelography, or whether it represents a direct toxic effect on the kidney similar to what must have occurred in Case 1 is open to speculation. These cases were all radiographed in other hospitals and only transferred to the regional dialysis unit when renal failure became apparent. Exact details of the dosage and radiological techniques used are therefore not available.

It has been pointed out in standard texts that patients suffering from pre-existing renal insufficiency may be pre- cipitated into acute renal failure by disturbances which in the normal person cause only minor changes in renal function (De Wardener, 1967). These include radiological contrast media, especially if used for aortography or in the presence of jaundice (Milne, 1967). Becker et al. (1968) advised that extra care be taken if renal failure is accompanied by jaundice.

Some advocates of high-dose radiology are reluctant to accept that the injected contrast media could have been responsible for the exacerbations of renal failure cited in the literature. Kelsey Fry and Cattell (1970) imply that some other factor-for example, dehydration-may have been responsible for the cases reported. Certainly the patient reported by Bergman et al. (1968) was inadvertently dehydrated, but this cannot be said of all the other instances in the literature to date. Even the oral administration of contrast media may not be without risk. Canales et al. (1969) have reported four cases of renal failure where the agent was iopanoic acid taken by mouth prior to cholecystography, and they make it clear that in their patients there was no clinical or laboratory evidence of parenchymatous hepatic dysfunction. Fortunately the incidence of serious complications is low, but our experience of four cases in a 12-month period should underline that it is not negligible, and we fear that ever-increasing doses of contrast media may increase the frequency and severity of cases unless great care is taken in the selection of patients to be examined in this way. The possibility of adverse side effects in any diagnostic procedure - must be weighed against the usefulness of the information it may provide. In the presence of renal disease or deep jaundice the complications of using contrast media may be very serious; an intravenous cholangiogram in particular is unlikely to be informative if the serum bilirubin is high.

\section{REFERENCES}

Ansell, G. (1968). Clinical Radiology, 19, 175.

Becker, J. A., Gregoire, A., Berdon, W., and Schwartz, D. (1968). Radiology, $90,243$.

Bergman, L. A., Ellison, M. R., and Dunea, G. (1968). New England Fournal of Medicine, 279, 1277.

Canales, C. O., Smith, G. H., Robinson, J. C., Remmers, A. R., and Sarles, H. E. (1969). New England Fournal of Medicine, 281, 89.

Chamberlain, M. J., and Gleeson, J. A. (1965), Lancet, 1, 619.

Fry, I. K., and Cattell, W. R. (1970). British fournal of Hospital Medicine, 3, 67 .

Lasser, E. C., Lang, J. H., and Zawadzki, Z. A. (1966). Fournal of the American Medical Association, 198, 945.

Manitz, G., and Matthes, K. J. (1967). Lancet, 2, 990.

Milne, M. D. (1967). In Renal Disease, ed. D. A. K. Black, 2nd edn., p. 556. Oxford, Blackwell Scientific.

Schencker, B. (1964). Radiology, 83, 12.

Schwartz, W. B., Hurwit, A., and Ettinger, A. (1963). New England fournal of Medicine, 269, 277. 